\title{
Comparison of ecological effects and costs of communal waste management systems
}

\author{
Peter Beigl, Stefan Salhofer* \\ Department of Waste Management, BOKU, University of Natural Resources and Applied Life Sciences Vienna, \\ Muthgasse 107, A-1190 Vienna, Austria
}

Received 20 September 2002; accepted 20 August 2003

\begin{abstract}
The selection of an appropriate "optimal" recycling alternative has to take into consideration both the ecological and economic effects of the entire life-cycle. The aim of this paper is to compare different waste management systems by means of a life-cycle assessment (LCA) and a cost comparison. The analysis uses data regarding the amount of household waste generated, collected and treated in a selected area in Austria. For this purpose, model-based scenarios with recycling and separate collection as well as scenarios without recycling were created. The database covers the amounts of household waste generated in the different collection schemes, the transport distances by private delivery and by regional waste management companies and data on the waste treatment processes that are widely employed throughout Austria and Germany. The resulting life-cycle inventories have been assessed according to three impact categories relevant to this topic - the global warming potential (GWP), the acidification potential (AP) and the net energy use (NEU). The results include ecological impact analyses and cost comparisons for the overall waste management systems and the waste management systems for the individual waste types-waste paper, plastic packaging, metal packaging and waste glass. Finally, a sensitivity analysis should prove the validity of the results for regions with transport distances differing from those in the area under analysis.
\end{abstract}

(C) 2003 Elsevier B.V. All rights reserved.

Keywords: Life-cycle assessment; Waste management system; Recycling; Waste management; Waste transport; Household waste

* Corresponding author: Tel.: +43-1-3189900-319; fax: +43-1-3189900-350.

E-mail address: stefan.salhofer@mail.boku.ac.at (S. Salhofer). 


\section{Introduction}

\subsection{Subject and aim of this analysis}

Over the last few years modern waste management has made great strides towards reducing the environmental impact and saving resources. Waste prevention measures and the development of advanced technologies for the recycling and disposal of waste have led to positive ecological effects. An approximation of the technological limits as well as increasingly more complicated logistics due to separate collection have to be taken into consideration in the recycling of certain waste types. Ecological benefits of recycling could subsequently be reduced or eliminated under certain regional conditions.

Austria's federal Waste Management $\mathrm{Law}^{1}$ regulates that after waste prevention options have been exhausted, "waste must be recycled when this is ecologically advantageous ... and when the resulting additional costs are not disproportionate compared to other waste treatment processes." A similar formulation can be found in Germany's corresponding Waste Management $\mathrm{Law}^{2}$. Here the principle can be interpreted that the ecological benefits of waste recycling must be higher than those of a disposal strategy without recycling and that additional costs should be taken into the bargain to a justifiable extent.

The aim of this paper is to compare the ecological effects and costs of different waste management systems. The analysis uses data regarding the amount of waste generated, collected and treated in a selected area in Austria and has created model-based scenarios with separate collection and recycling as well as scenarios without recycling. Finally, a sensitivity analysis verifies the general validity of the results.

\subsection{Methodological considerations}

Waste management systems include all technical and organisational components that channel the single waste groups (such as recyclables, residual waste, bulky waste, etc.) to specific waste treatment technologies (recycling, thermal treatment, etc.). Waste management systems without recycling do not require separate collection, whereas collection systems (as subsystems of a waste management system) play an important role in waste management systems that include recycling. The communal waste management systems discussed in this paper provide for the collection and treatment of waste from households and similar facilities.

Until recently the development of waste management systems had led to varying designs per region, for the most part determined by a specific framework, such as traditionally applied technologies, existing treatment plants and preferences in environmental policies. In Europe, for example, there are regions in which thermal treatment plants have been in operation for a long time, while in other regions recycling has been the preferred method of waste treatment (examples in Coopers and Lybrand, 1997).

To assess the various waste management systems and find the best solution, only individual components of the waste management systems were taken into consideration in the

\footnotetext{
1 Abfallwirtschaftsgesetz.

${ }^{2}$ Kreislaufwirtschafts- und Abfallgesetz.
} 
past. For example, Gallenkemper et al. (1992) compared collection systems by collection quantities, but the overall effect (such as saving primary resources through recycling) could not be overseen. Therefore, it is necessary to compare waste management systems within defined system boundaries (beginning with the production of the relevant materials in the waste stream and ending with recycling or disposal). For this kind of study only partial methods of analysis had been established at the time.

The chronological development of assessment methods for waste-related questions (Hartard, 2000) shows that in the first phase in the 1970s the environmental impact of certain products was examined, the first product-related life-cycle assessments (LCA). Thereafter methods for the assessment of production facilities were developed (environmental impact assessment ${ }^{3}$ ). Since the 1980 s waste treatment plants have been assessed, e.g. landfill sites (Seng, 1979), composting plants (Wiemer and Kern, 1992), treatment of residual waste (ITU and Öko-Institut Darmstadt, 1994) and mechanical-biological treatment plants (Koller and Soyez, 2001).

White et al. (1999) describes one of the few examples of an assessment of a waste management system, which includes an LCA approach to all the relevant materials in a municipal waste stream.

\subsection{Proceedings}

It was not possible to make a general comparison of the various waste management systems given the vast number of different waste management systems with varying amounts of waste generated and waste compositions. Hence we selected an area which the authors knew well from previous inquiries and for which specific data existed or was available by inquiry. Rural communities in two districts in the province of Salzburg (Austria) were selected for analysis. Specific data was available on the amount of waste generated and collected (Salhofer and Graggaber, 1998). The low density of settlement favoured the expectation of higher expenditures due to separate waste collection as well as subsequently clearer differences between the analysed scenarios and the same scenarios in urban areas.

For this area we examined the amount of communal waste generated and the actual practices of collection and treatment. In the next step three scenarios were defined. The amounts of waste generated, the vehicle journey lengths and the treatment technologies were attached to each of these scenarios. The ecological effects of the essential material groups of the communal waste stream were then put into balance extending from production over collection to recycling or disposal. White's (1999) IWM model was used as the base model and adapted by data modification according to the processes used in Austria and Germany.

\section{Analysed scenarios}

\subsection{Waste management systems}

Waste management systems differ primarily in terms of the realisation or the extent of recycling (waste management systems with recycling $(\mathrm{R})$ or without recycling $(\mathrm{NR})$ ). Waste

\footnotetext{
${ }^{3}$ Umweltvertraeglichkeitspruefung.
} 


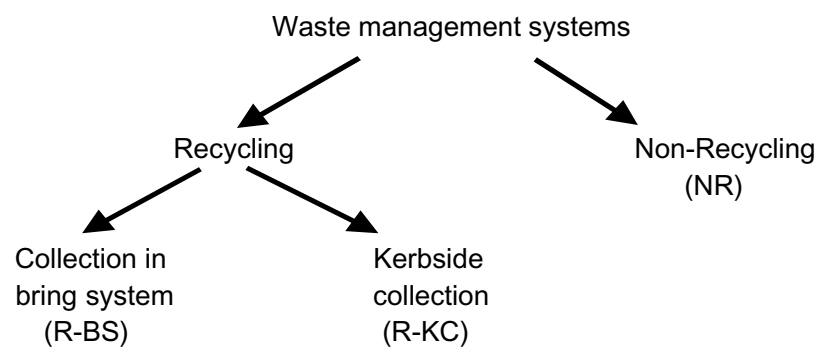

Fig. 1. Classification of waste management systems.

management systems with recycling can be distinguished by their predominate collection system—kerbside collection or bring system (Fig. 1).

In connection with this classification, we have developed three scenarios:

- Scenario R-BS (recycling, collection in the bring system): Residual waste and biowaste are collected by the regional waste management company from the property of the waste generator (collection transports with kerbside collection). All other waste types are brought to the next central collection site by private households and deposited there (individual transports in the bring system).

- Scenario $R-K C$ (recycling, kerbside collection): In addition to residual waste and biowaste, kerbside collection is also employed for waste paper, plastic packaging and metal packaging. Waste glass is not suitable for kerbside collection due to the low collection rate. Waste glass and all other waste types are collected at central collection sites in the bring system.

- Scenario NR (non-recycling): All waste types are collected kerbside without separation. The only waste types collected in the bring system contain those that cannot be collected kerbside (e.g. bulky waste, yard waste, cardboard) or are prohibited (hazardous waste).

\subsection{Waste treatment processes}

The waste treatment processes, used as a basis for the calculations, are widely employed throughout Austria and Germany, are regulated by law and come up to the state of the art. The relevant waste types go through the following treatment processes:

Residual waste: During mechanical-biological waste treatment, combustible fractions (paper, plastic) are separated by an air classifier, while ferrous metals are separated by a magnetic separator. After biodegradation, residues are disposed of in landfills. Separated ferrous metals are transported to materials recycling. Separated paper and plastic are thermally treated in fluidised bed incinerators. With regard to these materials, it is assumed that the separation under mechanical-biological waste treatment achieves the same level of efficiency as the separation under separate collection. Otherwise the product of this treat- 
Table 1

Analysed scenarios with attachment to the collection rates

\begin{tabular}{|c|c|c|c|c|}
\hline & Waste type & $\begin{array}{l}\text { R-BS (kg per } \\
\text { resident per } \\
\text { year) }\end{array}$ & $\begin{array}{l}\mathrm{R}-\mathrm{KC} \mathrm{kg} \text { per } \\
\text { resident per } \\
\text { year) }\end{array}$ & $\begin{array}{l}\mathrm{NR}(\mathrm{kg} \text { per } \\
\text { resident per } \\
\text { year })\end{array}$ \\
\hline \multirow{5}{*}{$\begin{array}{l}\text { Collection in kerbside } \\
\text { collection }\end{array}$} & Residual waste & 110.5 & 110.5 & 241.4 \\
\hline & Biowaste & 41.2 & 41.2 & \\
\hline & Waste paper & & 45.7 & \\
\hline & Packaging material & & $21.3^{\mathrm{a}}$ & \\
\hline & Total kerbside collection & 151.7 & 218.7 & 241.4 \\
\hline \multirow{9}{*}{$\begin{array}{l}\text { Collection in the bring } \\
\text { system }\end{array}$} & Waste paper & 45.7 & & \\
\hline & Waste glass & 22.7 & 22.7 & \\
\hline & Packaging material & $21.3^{\mathrm{a}}$ & & \\
\hline & $\begin{array}{l}\text { Bulky waste (incl. } \\
\text { Electric and electronic } \\
\text { equipment and wood) }\end{array}$ & 58.5 & 58.5 & 58.5 \\
\hline & Yard waste & 13.0 & 13.0 & 13.0 \\
\hline & Cardboard & 4.0 & 4.0 & 4.0 \\
\hline & Hazardous waste & 2.8 & 2.8 & 2.8 \\
\hline & Total bring system & 168.0 & 101.0 & 78.3 \\
\hline & Total & 319.7 & 319.7 & 319.7 \\
\hline
\end{tabular}

R-BS: recycling, bring system; R-KC: recycling, kerbside collection; NR: non-recycling.

${ }^{a}$ Containing $17.3 \mathrm{~kg}$ per resident per year plastic packaging and $4.0 \mathrm{~kg}$ per resident per year metal packaging

ment process could not match the requirements of the federal Austrian landfill ordinance concerning calorific content. ${ }^{4}$

- Organic waste: Biowaste and yard waste are composted in windrows and processed into compost.

- Plastic packaging: After manual sorting in conventional sorting facilities, the sorted item is recycled in plastic recycling facilities. Sorting residue is thermally treated in fluidised bed incinerators.

- Other materials: Waste paper, waste glass and metal packaging are recycled in the appropriate recycling facilities (paper mill, glass plant or metallurgical plant).

\section{Database}

\subsection{Waste amounts generated and collection systems}

Table 1 shows the collection rates of the three analysed waste management scenarios. Additional data on the composition of residual waste of this region were used to balance the ecological effects.

\footnotetext{
${ }^{4}$ This ordinance contains the regulation that the calorific content of the landfill input after mechanical-biological treatment must be below $6000 \mathrm{~kJ} / \mathrm{kg}$, an amount which depends substantially on the percentage of paper and plastic.
} 
Table 2

Fuel consumption for individual, collection and other transports

\begin{tabular}{|c|c|c|c|}
\hline Transporter & Process & Disposal area & $\begin{array}{l}\text { Fuel consumption } \\
\text { per ton waste }\end{array}$ \\
\hline Residents & $\begin{array}{l}\text { Individual } \\
\text { transports }\end{array}$ & $\begin{array}{l}\text { Mariapfarr } \\
\text { Knittelfeld (town) } \\
\text { Tamsweg } \\
\text { Knittelfeld (district) } \\
\text { St. Michael }\end{array}$ & $\begin{array}{c}33.2-63.8 \\
44.1 \\
31.1-36.9 \\
28.9 \\
15.3-20.9\end{array}$ \\
\hline \multirow{3}{*}{$\begin{array}{l}\text { Regional waste } \\
\text { management company }\end{array}$} & Collection transports & Knittelfeld (district) ${ }^{\mathrm{a}}$ & 10.9 \\
\hline & & $\begin{array}{l}\text { Untertauern } \\
\text { Pongau (district) } \\
\text { Knittelfeld (town) }\end{array}$ & $\begin{array}{r}10.5 \\
7.7 \\
5.8\end{array}$ \\
\hline & Other transports & $\begin{array}{l}\text { Knittelfeld (district) } \\
\text { Knittelfeld (town) }^{\mathrm{a}} \\
\text { Pongau (district) }\end{array}$ & $\begin{array}{l}2.7 \\
2.4 \\
2.3\end{array}$ \\
\hline
\end{tabular}

${ }^{a}$ Comparison values from Schwaiger (1996).

\subsection{Transports}

Waste disposal transports for have been distinguished into individual transports (private delivery in the bring system by car), collection transports (kerbside collection with waste collection trucks) and other transports (collection in the bring system and transport to waste treatment facilities).

An approximation of the distance covered by the individual transports was based on inquiries at central collection sites in three rural communities in the analysed area. Visitor frequency and the average car journey length of the residents to the collection site were determined through interviews. The average car journey length of each community ranged between 2.7 and $35.7 \mathrm{~km}$ per resident per year. This corresponds to a fuel consumption of 0.29 to 3.831 per resident per year.

The distances for the collection and other transports were calculated for the analysed area by means of interviews with the manager of the regional waste management company whose task was to collect the waste in 25 rural communities with 77,000 inhabitants. Using the data on average diesel consumption and journey length per collection truck per day as well as the total annual operation time of the fleet of trucks, we calculated an average truck journey length of $3.29 \mathrm{~km}$ and diesel consumption of 1.451 per resident per year of collection transports.

Estimations for other transports were based on information about the journey lengths to waste treatment facilities and the specific diesel consumption and loading capacity of the trucks and led to an average journey length of $2.71 \mathrm{~km}$ per resident per year and diesel consumption of 0.721 per resident per year.

The comparison of fuel consumption (per ton waste) shows a clearly higher fuel consumption for individual transports compared to the transports of the regional waste management companies (Table 2). The values for the Pongau district (collection and other transports) and the average values for the communities of Mariapfarr, Tamsweg and St. Michael have been selected as input parameters for the following calculations. 
Table 3

Analysed processes, ecological effects and process parameters

\begin{tabular}{|c|c|c|c|c|}
\hline \multirow{2}{*}{$\begin{array}{l}\text { Waste types } \\
\begin{array}{l}\text { Residual and } \\
\text { bulky waste }\end{array}\end{array}$} & \multicolumn{2}{|l|}{ Process } & \multirow{2}{*}{$\begin{array}{l}\begin{array}{l}\text { Ecological } \\
\text { effects }\end{array} \\
\begin{array}{l}\text { Electrical net } \\
\text { energy use }\end{array}\end{array}$} & \multirow{2}{*}{$\begin{array}{l}\begin{array}{l}\text { Process } \\
\text { parameters }\end{array} \\
120 \mathrm{kWh} / \mathrm{t}\end{array}$} \\
\hline & Mechanical-biologic & waste treatment & & \\
\hline & $\begin{array}{l}\text { Thermal treatment } \\
\text { of combustible } \\
\text { residues }\end{array}$ & Paper & Air emissions & $\begin{array}{l}20 \%(\mathrm{R}), \\
75 \%(\mathrm{NR})^{\mathrm{a}}\end{array}$ \\
\hline & & & $\begin{array}{l}\text { Energy savings } \\
\text { (natural gas } \\
\text { equivalent) }\end{array}$ & $234.4 \mathrm{Nm} 3 / \mathrm{t}$ \\
\hline & & Plastic & Air emissions & $\begin{array}{l}30 \%(\mathrm{R}) \\
70 \%(\mathrm{NR})^{\mathrm{a}}\end{array}$ \\
\hline & & & $\begin{array}{l}\text { Energy savings } \\
\text { (Natural gas } \\
\text { equivalent) }\end{array}$ & $390.6 \mathrm{Nm} 3 / \mathrm{t}$ \\
\hline & $\begin{array}{l}\text { Materials } \\
\text { recycling }\end{array}$ & $\begin{array}{l}\text { Ferrous metals } \\
\text { separated }\end{array}$ & $\begin{array}{l}\text { Energy savings } \\
\text { and emissions } \\
\text { reductions }{ }^{\text {b }}\end{array}$ & $80 \%{ }^{\mathrm{a}}$ \\
\hline & Landfill & $\begin{array}{l}\text { Compression with } \\
\text { compactors }\end{array}$ & $\begin{array}{l}\text { Diesel } \\
\text { consumption }\end{array}$ & $21 / t$ \\
\hline & & $\begin{array}{l}\text { Landfill gas } \\
\text { production }\end{array}$ & Air emissions & $6.2 \mathrm{Nm} 3 / \mathrm{t}$ \\
\hline \multirow[t]{2}{*}{ Organic waste } & \multirow{2}{*}{\multicolumn{2}{|c|}{ Compost production }} & $\begin{array}{l}\text { Electrical net } \\
\text { energy use }\end{array}$ & \\
\hline & & & Emissions & Collection rate ${ }^{c}$ \\
\hline \multirow[t]{6}{*}{ Plastic packaging } & Collection & $\begin{array}{l}\text { Polyethylene bags } \\
\text { (production) }\end{array}$ & $\begin{array}{l}\text { Emissions and } \\
\text { energy use }\end{array}$ & $\begin{array}{l}\text { Material } \\
\text { consumption }^{\mathrm{c}}\end{array}$ \\
\hline & Sorting & & $\begin{array}{l}\text { Electrical net } \\
\text { energy use }\end{array}$ & $67 \mathrm{kWh} / \mathrm{t}$ \\
\hline & \multirow[t]{2}{*}{$\begin{array}{l}\text { Materials } \\
\text { recycling }\end{array}$} & Film & $\begin{array}{l}\text { Energy savings } \\
\text { and emissions } \\
\text { reductions }{ }^{\text {b }}\end{array}$ & $\begin{array}{l}25 \% \text { of the } \\
\text { collection rate }^{c}\end{array}$ \\
\hline & & Rigid & $\begin{array}{l}\text { Energy savings } \\
\text { and emissions } \\
\text { reductions }{ }^{b}\end{array}$ & $\begin{array}{l}25 \% \text { of the } \\
\text { collection rate }^{c}\end{array}$ \\
\hline & \multirow[t]{2}{*}{ Thermal treatment } & \multirow[t]{2}{*}{ Sorting residues } & Air emissions & $\begin{array}{l}50 \% \text { of the } \\
\text { collection rate }\end{array}$ \\
\hline & & & $\begin{array}{l}\text { Energy savings } \\
\text { (Natural gas } \\
\text { equivalent) }\end{array}$ & $390.6 \mathrm{Nm} 3 / \mathrm{t}$ \\
\hline $\begin{array}{r}\text { Waste paper } \\
\text { cardboard }\end{array}$ & \multicolumn{2}{|l|}{ Materials recycling } & $\begin{array}{l}\text { Energy savings } \\
\text { and emissions } \\
\text { reductions }{ }^{\mathrm{b}}\end{array}$ & Collection rate $\mathrm{c}^{\mathrm{c}}$ \\
\hline Waste glass & \multicolumn{2}{|l|}{ Materials recycling } & $\begin{array}{l}\text { Energy savings } \\
\text { and emissions } \\
\text { reductions }{ }^{b}\end{array}$ & Collection rate ${ }^{c}$ \\
\hline Metals & $\begin{array}{l}\text { Materials } \\
\text { recycling }\end{array}$ & Ferrous metals & $\begin{array}{l}\text { Energy savings } \\
\text { and emissions } \\
\text { reductions }{ }^{\text {b }}\end{array}$ & Collection rate ${ }^{c}$ \\
\hline
\end{tabular}


Table 3 (Continued)

\begin{tabular}{lllll}
\hline Waste types & Process & & $\begin{array}{l}\text { Ecological } \\
\text { effects }\end{array}$ & $\begin{array}{l}\text { Process } \\
\text { parameters }\end{array}$ \\
\hline & & $\begin{array}{l}\text { Non-ferrous } \\
\text { metals }\end{array}$ & $\begin{array}{l}\text { Energy savings } \\
\text { and emissions } \\
\text { reductions }\end{array}$ & Collection rate $^{\mathrm{c}}$ \\
Each waste type & Transports & Air emissions & \\
& $\begin{array}{l}\text { Collection } \\
\text { container }\end{array}$ & $\begin{array}{l}\text { Folypropylene } \\
\text { bins (production) }\end{array}$ & $\begin{array}{l}\text { Air emissions } \\
\text { and energy use }\end{array}$ & $\begin{array}{l}\text { (petrol, diesel) } \\
\text { Material } \\
\text { consumption }^{\mathrm{c}}\end{array}$ \\
\hline
\end{tabular}

\footnotetext{
${ }^{a}$ Efficiency of separation as a percentage of the mass input of each waste fraction.

b Energy savings and emissions reductions by means of materials recycling relative to the production of raw material.

${ }^{c}$ Depending on the waste management system.
}

\subsection{Processes and ecological effects}

The processes and ecological effects that were taken into consideration (Table 3) were based on White's (1999) model, which contains life-cycle inventories of materials recycling by waste type, energy resource (natural gas, electrical energy, petrol, diesel), burning of plastic and paper and landfill gas production under typical conditions in Central and Western Europe. Each process parameter was adapted to Austrian and German standards.

\subsection{Cost}

The database for calculating the cost of each waste management system includes the cost of the transports for the regional waste management company (collection and other

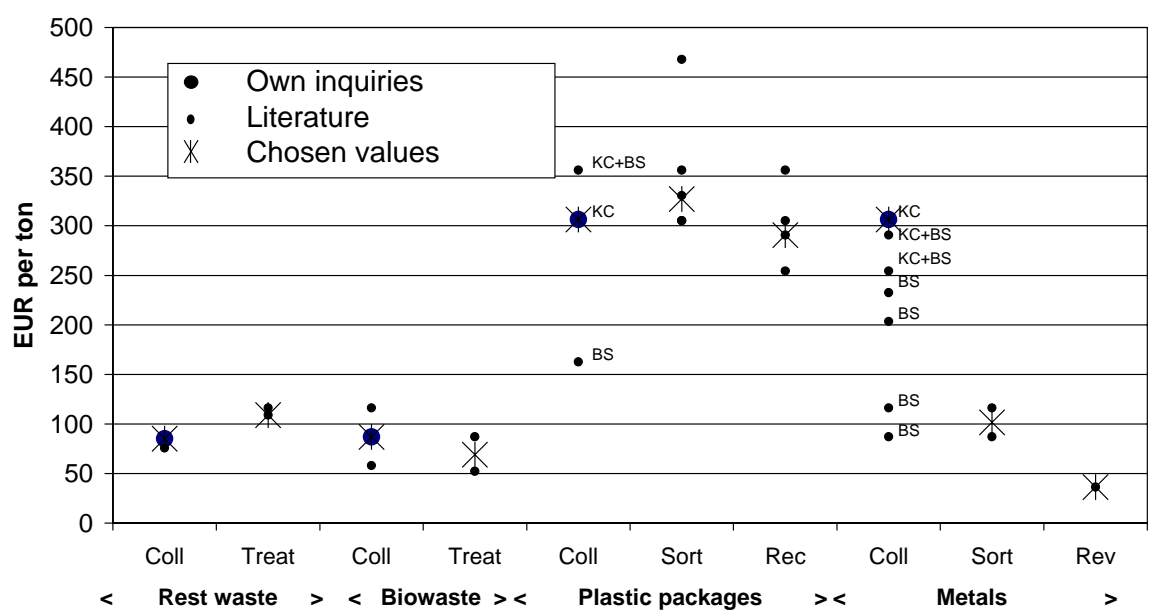

Fig. 2. Cost and value assessments of cost relevant waste fractions. Abbreviation: Coll—collection; Treat—-treatment (include landfill); sort—sorting; Rec—recycling; Rev—revenue. 
transports), individual transports of residents by car, waste treatment processes (Chapter 3.3) and the use of collection containers. The cost of public relations and managing the collection sites as well as the opportunity cost (derived from how residents spend their time) have not been taken into consideration due to the lack of reliable data.

The cost of the individual transports was assessed as the official mileage allowance under Austrian tax law. The remaining cost and value assessments were selected on the basis of inquiries and findings in the relevant scientific literature (Fig. 2).

\section{Calculations}

\subsection{Ecological effects}

The life-cycle inventory was calculated using simple arithmetic on the basis of process related life-cycle inventories by White, researched process parameters and assumptions concerning the collection rate and transport expenditures.

The impact categories - the global warming potential, the acidification potential (AP) and the net energy use (NEU) - served as measures for balancing the impact assessments. The selection of the applied impact categories was based on their relevance to this topic (importance of traffic and waste treatment processes), the ability to quantify ecological effects and the acknowledgement of the methods used. Each parameter was attached to the corresponding impact category by equivalent factors (Table 4). The results are expressed as a percentage of the total ecological impact $\left(8.360 \mathrm{~kg} \mathrm{CO}_{2}\right.$ eq., $41.85 \mathrm{~kg} \mathrm{SO}_{2}$ eq.) and net energy use $(162.5 \mathrm{GJ})$ per resident and year. Switzerland in 1997 was chosen as the area and year of reference because of the lack of up-to-date and complete environmental data for Austria (BUWAL, 1998). The existing Austrian data, which lie in the range of the Swiss data, prove the similarity of the ecological impact in these two countries.

\subsection{Cost calculation}

A cost calculation was made by linking quantity measures (e.g. collection rates, process inputs) to the chosen cost and value assessments. A linear linkage between the quantities

Table 4

Impact categories and equivalents (Borken et al., 1999)

\begin{tabular}{lllr}
\hline Impact category & Measure & Parameters & Equivalent factors \\
\hline Global warming & $\mathrm{CO}_{2}$ equivalent & Carbon dioxide $\left(\mathrm{CO}_{2}\right)$ & 1 \\
Potential (GWP) & & Methane $\left(\mathrm{CH}_{4}\right)$ & 21 \\
& & Laughing gas $\left(\mathrm{NO}_{2}\right)$ & 310 \\
Acidification & $\mathrm{SO}_{2}$ equivalent & Sulphur dioxide $\left(\mathrm{SO}_{2}\right)$ & 1 \\
Potential (AP) & & Nitrogen oxides $\left(\mathrm{No}_{x}\right)$ & 0.7 \\
& & Ammonia $\left(\mathrm{NH}_{3}\right)$ & 1.88 \\
Net energy use (NEU) & Joule & Hydrogen chloride $(\mathrm{HCl})$ & 0.88 \\
\hline
\end{tabular}




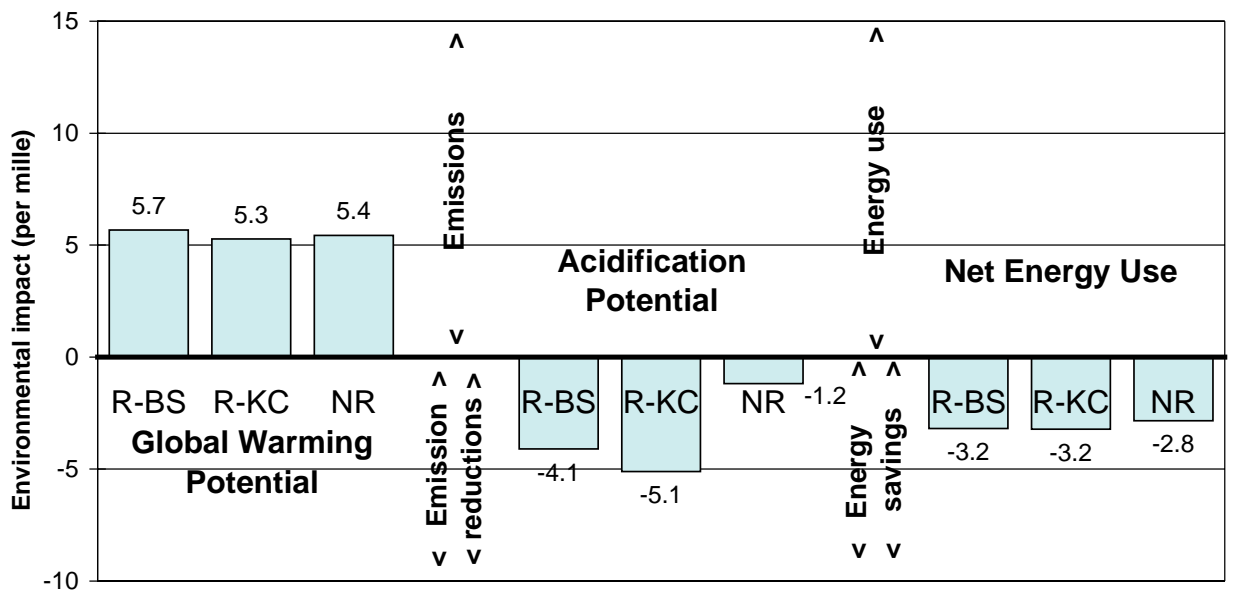

Fig. 3. Comparison of ecological effects of waste management systems.

and the resulting cost were assumed because of the quality of the existing data. A cost digression, which can play an important role particularly in the case of waste treatment facilities with a large capacity, was not taken into account.

\section{Results}

\subsection{Ecological impact}

The results of calculating the environmental impact are shown in Fig. 3 and Table 5. Plus signs indicate an environmental impact (air emissions and energy use) and minus signs show environmental discharges (emissions reductions and energy savings). If we compare the various waste management scenarios, the recycling scenarios show clear advantages in terms of the acidification and net energy use impact categories. In comparing the global warming emissions, recycling with kerbside collection shows fewer emissions than the non-recycling scenario and recycling in the bring system.

The comparison of the different recycling scenarios determines the ecological benefits of kerbside collection relative to collection in the bring system for each impact category. The benefits are due to lower fuel consumption for collection transports (kerbside) versus individual transports (Table 2).

Specific results for the recycling or disposal of waste paper are shown in Table 6. The NR scenario (when paper is separated in the mechanical-biological waste treatment and treated thermally) leads to clear ecological benefits with regard to the global warming potential and net energy use impact categories as compared to the recycling scenarios ${ }^{5}$. The

\footnotetext{
5 Tiedemann's (2000) life-cycle assessment of graphic papers led to similar findings. The comparison of a recycling option with a thermal treatment option (thermal use in power- and heat-supply stations) has shown significant advantages with the same impact categories.
} 
Table 5

Ecological effects of waste management systems by processes (per mille of the total environmental impact)

\begin{tabular}{|c|c|c|c|c|c|c|c|c|c|c|}
\hline & & \multicolumn{3}{|c|}{ Global warming potential } & \multicolumn{3}{|c|}{ Acidification potential } & \multicolumn{3}{|c|}{ Net energy use } \\
\hline & & R-BS & $\mathrm{R}-\mathrm{KC}$ & NR & R-BS & $\mathrm{R}-\mathrm{KC}$ & NR & R-BS & $\mathrm{R}-\mathrm{KC}$ & NR \\
\hline \multirow{4}{*}{$\begin{array}{l}\text { Collection and } \\
\text { treatment }\end{array}$} & Transports & 2.51 & 1.95 & 1.63 & 5.96 & 4.58 & 3.80 & 2.00 & 1.53 & 1.28 \\
\hline & Collection container & 0.13 & 0.28 & 0.09 & 0.35 & 0.73 & 0.24 & 0.38 & 0.81 & 0.26 \\
\hline & $\begin{array}{l}\text { Treatment of residual waste, } \\
\text { bulky waste and biowaste }\end{array}$ & 1.29 & 1.29 & 2.42 & 1.31 & 1.31 & 2.56 & 0.91 & 0.91 & 1.78 \\
\hline & Total collection and treatment & 3.93 & 3.52 & 4.14 & 7.63 & 6.63 & 6.60 & 3.29 & 3.26 & 3.31 \\
\hline \multirow[t]{5}{*}{ Recycling } & Waste paper & -0.28 & -0.28 & -2.68 & -6.87 & -6.87 & -4.37 & -2.26 & -2.26 & -2.90 \\
\hline & Plastic packaging & 2.23 & 2.23 & 4.07 & -2.05 & -2.05 & -2.28 & -2.14 & -2.14 & -2.12 \\
\hline & Metals & -0.12 & -0.12 & -0.10 & -2.02 & -2.02 & -1.15 & -1.56 & -1.56 & -1.14 \\
\hline & Waste glass & -0.08 & -0.08 & & -0.80 & -0.80 & & -0.52 & -0.52 & \\
\hline & Total recycling savings & 1.76 & 1.76 & 1.30 & -11.73 & -11.73 & -7.79 & -6.48 & -6.48 & -6.16 \\
\hline Total overall & & 5.68 & 5.28 & 5.44 & -4.10 & -5.11 & -1.19 & -3.19 & -3.22 & -2.84 \\
\hline
\end{tabular}

Note: negative figures represent emissions reductions or energy savings. 
Table 6

Comparison of waste management scenarios for waste paper (per mille of the total environmental impact)

\begin{tabular}{|c|c|c|c|c|c|c|c|c|c|c|}
\hline & & \multicolumn{3}{|c|}{ Global warming potential } & \multicolumn{3}{|c|}{ Acidification potential } & \multicolumn{3}{|c|}{ Net energy use } \\
\hline & & R-BS & $\mathrm{R}-\mathrm{KC}$ & NR & R-BS & $\mathrm{R}-\mathrm{KC}$ & NR & R-BS & $\mathrm{R}-\mathrm{KC}$ & NR \\
\hline \multirow[t]{4}{*}{ Collection and treatment } & Transports & 0.56 & 0.17 & 0.13 & 1.36 & 0.38 & 0.29 & 0.46 & 0.13 & 0.09 \\
\hline & Collection container & & 0.06 & 0.02 & & 0.18 & 0.05 & & 0.19 & 0.05 \\
\hline & Thermal treatment & & & & 0.11 & 0.11 & 1.65 & $<0.01$ & $<0.01$ & 0.05 \\
\hline & Total collection and treatment & 0.56 & 0.23 & 0.15 & 1.47 & 0.67 & 1.99 & 0.46 & 0.32 & 0.19 \\
\hline \multirow[t]{3}{*}{ Recycling } & Materials recycling & -0.10 & -0.10 & -0.01 & -6.61 & -6.61 & -0.53 & -2.08 & -2.08 & \\
\hline & $\begin{array}{l}\text { Thermal treatment } \\
\text { (Nat. gas equivalent) }\end{array}$ & -0.18 & -0.18 & -2.67 & -0.37 & -0.37 & -5.49 & -0.19 & -0.19 & -3.00 \\
\hline & Total recycling & -0.28 & -0.28 & -2.68 & -6.98 & -6.98 & -6.02 & -2.27 & -2.27 & -3.00 \\
\hline Total & & 0.29 & -0.04 & -2.53 & -5.51 & -6.31 & -4.03 & -1.81 & -1.95 & -2.80 \\
\hline
\end{tabular}

Note: negative figures represent emissions reductions or energy savings. 
reason for this effect is that carbon dioxide emissions produced by thermal treatment are not considered relevant for global warming because of the natural origin of the raw material wood, which has been produced in sustainably managed forests. This corresponds to the generally accepted proceedings for life-cycle assessments where carbon dioxide emissions need to be taken into account only in the burning of fossil energy resources. Nevertheless, what has not been taken into consideration is that carbon dioxide is produced far quicker by burning than by the humification of wood in the soil as part of the biological cycle (Klein Goldewijk and Leemans, 1995; Harvey et al., 2000; Schlesinger et al., 2000). With regard to the acidification potential impact category, the R-KC scenario shows the lowest environmental impact. Because pollution policies place a generally higher importance on the global warming effect than on the acidification potential, the thermal treatment of waste paper and cardboard - under the aforementioned methodological restrictions - can be regarded as the scenario with the lowest environmental impact. The comparison of the recycling scenarios with kerbside collection and the bring system shows a significantly longer transport distance in the bring system due to higher fuel consumption as a result of individual transports (Table 2).

The disposal of plastic packaging without recycling (scenario NR) means on the one hand a $66 \%$ higher environmental impact in terms of the global warming effect and on the other hand significantly higher reductions in acid emissions and energy savings (Table 7). The negative contribution to the global warming effect is due to the thermal treatment of plastic residues during mechanical-biological treatment. Burning plastic results in threefold greater emissions compared to the volume of natural gas containing the same calorific content. If we suppose that the global warming effect has a higher importance, the recycling scenarios should then be classified as ecologically better. The difference between the fuel emissions in kerbside collection and collection in the bring system is less significant here than for waste paper collection because the low bulk density of plastic packaging leads to a fundamental increase in fuel consumption for the collection transports.

The recycling of metal packaging and waste glass leads to clear ecological benefits in terms of acidification and net energy use. The global warming potential does not differ significantly in each of the scenarios. The collection of metal packaging (like the collection of plastic packaging) does not show a clear difference between kerbside collection and collection in the bring system.

Table 8 provides a summary of the results for each waste type. The global warming potential (GWP) impact category is used as the primary criterion for ranking. The acidification potential (AP) and net energy use (NEU) impact categories were chosen as subsequent ranking criteria when there were no big differences in terms of GWP (Table 9).

\subsection{Cost}

The cost comparison shows no significantly higher costs in the recycling scenarios $(+11 \%$ (R-BS) and $+21 \%$ (R-KC)) versus the scenario without recycling (Table 8). The cost comparison for the waste management scenarios of certain waste types proves the costs are higher for the recycling of plastic packaging. For metal packaging kerbside collection is 
Table 7

Comparison of waste management scenarios for plastic packaging (per mille of the total environmental impact)

\begin{tabular}{|c|c|c|c|c|c|c|c|c|c|c|}
\hline & & \multicolumn{3}{|c|}{ Global warming potential } & \multicolumn{3}{|c|}{ Acidification potential } & \multicolumn{3}{|c|}{ Net energy use } \\
\hline & & R-BS & $\mathrm{R}-\mathrm{KC}$ & NR & R-BS & $\mathrm{R}-\mathrm{KC}$ & NR & R-BS & $\mathrm{R}-\mathrm{KC}$ & NR \\
\hline \multirow[t]{5}{*}{ Collection and treatment } & Transports & 0.23 & 0.18 & 0.05 & 0.55 & 0.39 & 0.11 & 0.19 & 0.13 & 0.04 \\
\hline & Collection bags & & 0.07 & & & 0.16 & & & 0.20 & \\
\hline & Thermal treatment & 3.61 & 3.61 & 6.13 & 1.15 & 1.15 & 1.96 & 0.01 & 0.01 & 0.02 \\
\hline & Sorting & 0.06 & 0.06 & & 0.09 & 0.09 & & 0.07 & 0.07 & \\
\hline & Total collection and treatment & 3.90 & 3.92 & 6.18 & 1.80 & 1.80 & 2.06 & 0.27 & 0.41 & 0.06 \\
\hline \multirow[t]{3}{*}{ Recycling } & Materials recycling & -0.23 & -0.23 & & -0.80 & -0.80 & & -0.95 & -0.95 & \\
\hline & $\begin{array}{l}\text { Thermal treatment } \\
\text { (natural gas equivalent) }\end{array}$ & -1.21 & -1.21 & -2.06 & -2.49 & -2.49 & -4.23 & -1.26 & -1.26 & -2.15 \\
\hline & Total recycling & -1.44 & -1.44 & -2.06 & -3.29 & -3.29 & -4.23 & -2.22 & -2.22 & -2.15 \\
\hline Total overall & & 2.46 & 2.48 & 4.12 & -1.50 & -1.49 & -2.17 & -1.95 & -1.81 & -2.09 \\
\hline
\end{tabular}

Note: negative figures represent emissions reductions or energy savings. 
Table 8

Comparison of waste management systems of waste types (per mille of the total environmental impact)

\begin{tabular}{|c|c|c|c|c|c|c|c|c|c|c|c|}
\hline \multirow[t]{2}{*}{ Impact category } & \multicolumn{3}{|c|}{ Waste paper } & \multicolumn{3}{|c|}{ Plastic packaging } & \multicolumn{3}{|c|}{ Metal packaging } & \multicolumn{2}{|c|}{ Waste glass } \\
\hline & R-BS & $\mathrm{R}-\mathrm{KC}$ & NR & R-BS & $\mathrm{R}-\mathrm{KC}$ & NR & R-BS & $\mathrm{R}-\mathrm{KC}$ & NR & R-BS & NR \\
\hline Global warming potential (GWP) & 0.29 & -0.04 & -2.53 & 2.46 & 2.48 & 4.12 & 0.01 & 0.02 & -0.01 & 0.22 & 0.18 \\
\hline Acidification potential (AP) & -5.51 & -6.31 & -4.03 & -1.50 & -1.49 & -2.17 & -1.18 & -1.16 & -0.40 & -0.08 & 0.32 \\
\hline Net energy use (NEU) & -1.81 & -1.95 & -2.80 & -1.95 & -1.81 & -2.09 & -0.84 & -0.79 & -0.44 & -0.28 & 0.17 \\
\hline Ranking & 2 & 3 & 1 & 1 & 2 & 3 & 1 & 2 & 3 & 1 & 2 \\
\hline Ranking criteria & GWP & & & GWP & & & $\mathrm{AP}, \mathrm{NH}$ & & & $\mathrm{AP}, \mathrm{NH}$ & \\
\hline
\end{tabular}

Note: Negative figures represent emissions reductions or energy savings. 
Table 9

Cost of waste management scenarios (€per resident and year)

\begin{tabular}{lrrr}
\hline Process & R-BS & R-KC & NR \\
\hline Collection and other transports & 21.87 & 32.12 & 23.69 \\
Individual transports & 18.24 & 10.76 & 8.28 \\
Collection container & 4.58 & 7.70 & 2.25 \\
Waste treatment (incl. Recycling and landfill) & 25.72 & 25.72 & 29.00 \\
Total & 70.42 & 76.38 & 63.29 \\
\hline
\end{tabular}

significantly more expensive than collection in the bring system due to the lower bulk density in the collection trucks and the lower collection rate (Table 10).

\subsection{Summary of regional results}

In comparison to the non-recycling scenario, the recycling scenarios lead to clear energy savings and reductions in acid emissions plus a similar amount of emissions affecting global warming and cost. The recycling of waste glass and metal packaging leads to clear ecological benefits. Waste glass recycling reduces costs, whereas recycling of metal packaging causes few additional costs in the bring system and high additional costs in the case of kerbside collection. Although the materials recycling of plastic packaging is ecologically advantageous, it causes much higher collection and treatment costs.

The thermal treatment of waste paper is able to contribute to substantial reductions in global warming emissions as well as energy savings compared with materials recycling. Nevertheless this result is based on the assumption that carbon dioxide emissions from burning do not have to be viewed as relevant for global warming because of the natural origin of the raw material wood. It has not been taken into consideration that carbon dioxide is produced more quickly through burning than through the humification of wood in the biological cycle (Klein Goldewijk and Leemans, 1995; Harvey et al., 2000; Schlesinger et al., 2000). The comparison of kerbside collection and collection in the bring system points to the fact that kerbside collection is ecologically better for waste paper or at least equal for plastic packaging and metal packaging. The kerbside collection of metal packaging leads to fundamentally higher costs.

Table 10

Comparison of disposal costs of the analysed waste types (Euro cents per kilogram)

\begin{tabular}{llr}
\hline Waste type & R-BS & $\mathrm{R}^{\mathrm{a}}-\mathrm{KC}^{\mathrm{a}}$ \\
\hline Plastic packaging & 79 & 103 \\
Metal packaging & 24 & 47 \\
Waste paper & 11 & 13 \\
Waste glass & 11 & - \\
\hline
\end{tabular}

${ }^{\mathrm{a}} \mathrm{NR}=21$ (disposal as residual waste with kerbside collection). 


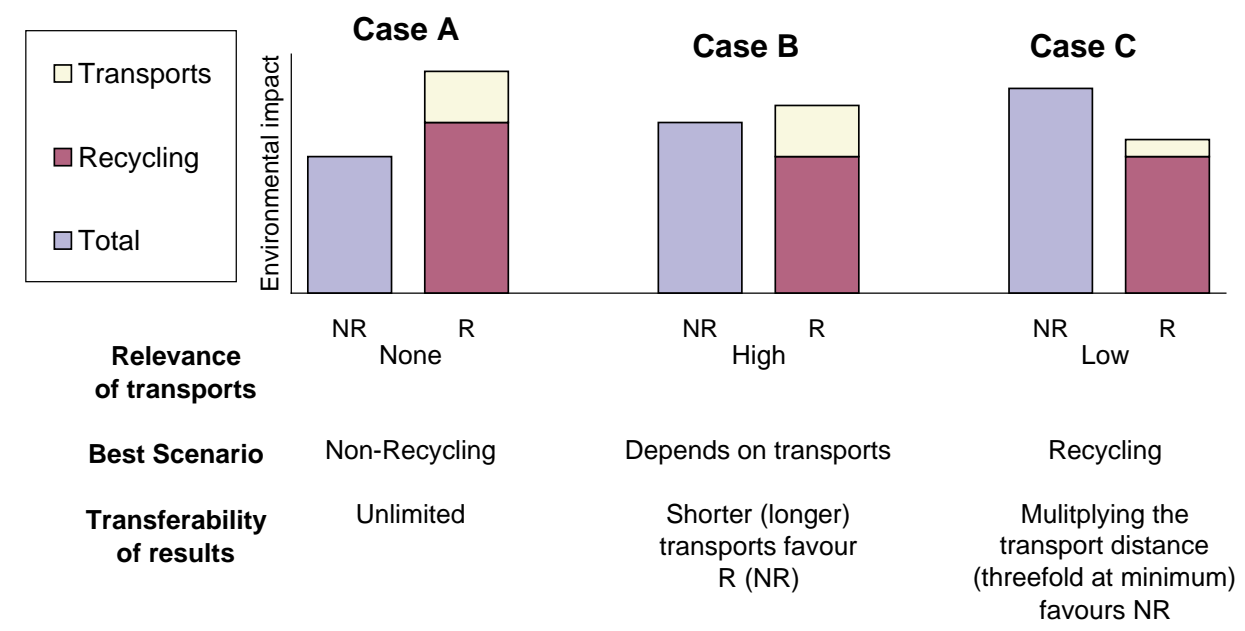

Fig. 4. Influence of the transport distance on the ecological benefits of recycling vs. non-recycling.

\subsection{Validity of results}

If we apply the above mentioned waste treatment processes (Chapter 2.2), the ecological and cost rankings for the waste management system scenarios can be transferred to the disposal areas with similar amounts of waste generated (with special consideration for the composition of the waste) and to shorter transport distances.

Concerning the impact of the distance of the waste transports on the environmental effect, three cases can be distinguished (Fig. 4). In Case A, the environmental impact of the recycling variant exceeds the non-recycling variant even with no transports. In Case C, the emissions reductions through recycling are so large that even big transport distances could not approach the environmental impact of the non-recycling variant. Thus transport distances also have little influence on the total result. Only in Case B do the transport distances have a high relevance for the total result.

The sensitivity analysis shows that only in the case of disposal of metal packaging (concerning GWP) and waste glass (concerning NEU and AP) does an increase in the transport distances favours the NR scenario (Table 11). The low density of settlement in the analysed

Table 11

Results of the relevance of the transports in the analysed area

\begin{tabular}{lll}
\hline $\begin{array}{l}\text { Case } \mathrm{A}, \text { no relevance } \\
\text { of transports }\end{array}$ & $\begin{array}{l}\text { Case } \mathrm{B}, \text { high relevance of } \\
\text { transports }\end{array}$ & $\begin{array}{l}\text { Case C, low relevance of } \\
\text { transports }\end{array}$ \\
\hline Waste paper (GWP, NEU) & Waste glass (AP, GWP) & Plastic packaging (GWP) \\
Plastic packaging (AP, NEU) & Metal packaging (GWP) & $\begin{array}{l}\text { Waste glass (NEU) } \\
\text { Metal packaging (AP, NEU) }\end{array}$ \\
& & Waste paper (AP)
\end{tabular}

Note: underlined are those impact categories relevant to the ranking of the scenarios for this waste type (Table 8). 
Table 12

Results of the comparison of communal waste management systems

\begin{tabular}{|c|c|c|c|c|}
\hline Waste type & Waste paper & Waste glass & Plastic packaging & Metal packaging \\
\hline $\begin{array}{l}\text { Ecologically best waste } \\
\text { management scenario }\end{array}$ & $\begin{array}{l}\text { Non-recycling } \\
\text { (thermal treatment) }\end{array}$ & Recycling & Recycling & Recycling \\
\hline Relevant impact categories & $\begin{array}{l}\text { Global warming } \\
\text { potential } \\
\text { Net energy use }\end{array}$ & $\begin{array}{l}\text { Net energy use } \\
\text { Acidification } \\
\text { potential }\end{array}$ & $\begin{array}{l}\text { Global warming } \\
\text { potential }\end{array}$ & $\begin{array}{l}\text { Acidification } \\
\text { potential } \\
\text { Net energy use }\end{array}$ \\
\hline $\begin{array}{l}\text { Ecological relevance of } \\
\text { transports in the analysed area }\end{array}$ & None & High (AP, GWP) & Negligible & $\begin{array}{l}\text { High for GWP, but low } \\
\text { influence on the ranking }\end{array}$ \\
\hline $\begin{array}{l}\text { Transferability of the results to } \\
\text { areas with longer transports }\end{array}$ & Unlimited & $\begin{array}{l}\text { Conditional } \\
\text { (AP, GWP) }\end{array}$ & $\begin{array}{l}\text { Good (up to eight-fold } \\
\text { transport distance) }\end{array}$ & $\begin{array}{l}\text { Good (low influence of } \\
\text { GWP on the ranking) }\end{array}$ \\
\hline $\begin{array}{l}\text { Cost of the recycling scenarios } \\
\text { compared with non-recycling }\end{array}$ & $\begin{array}{l}\text { Lower } \\
\text { BS: }-38 \% \text {; } \\
\text { KC: }-48 \% \\
\end{array}$ & Lower $(-48 \%)$ & $\begin{array}{l}\text { Higher } \\
\text { BS: factor } 3.7 \text {; } \\
\text { KC: factor } 4.8\end{array}$ & $\begin{array}{l}\text { Higher } \\
\text { BS: }+12 \% \text {; } \\
\text { KC: }+124 \% \\
\end{array}$ \\
\hline
\end{tabular}


area favours the expectation that there would be no change in the ranking of the scenarios if a given urban and/or rural area would have a higher density of settlement. In terms of the cost comparison, shorter transport distances also favour the recycling scenarios due to the higher percentage of the transport cost versus the non-recycling scenario (Table 10).

\section{Conclusions}

\subsection{Waste management of materials}

The results of the comparison of selected communal waste management systems have led to the following conclusions with regard to waste types (Table 12):

- The non-recycling scenario for waste paper effects clear reductions in global warming emissions as well as energy savings if we do not take into account the emissions from thermal treatment because of the natural origin of this material ${ }^{6}$. This scenario without recycling is connected with higher costs than the recycling scenarios.

- The materials recycling of plastic packaging leads to clearly lower global warming emissions but to very high additional costs.

- The separate collection and recycling of metal packaging is ecologically advantageous. Kerbside collection leads to fundamentally higher additional costs.

- The recycling of waste glass is beneficial in terms of both the ecological and cost criteria.

\subsection{Waste management systems}

With a view to improving the waste management systems, the results have led us to the following findings:

- The cost comparison shows relatively small differences in the analysed waste management systems. Bearing in mind the principles of the federal Austrian Waste Management Law, ${ }^{7}$ favour has to be given to recycling because of the ecological benefits and the justifiable additional costs.

- Kerbside collection is ecologically better than collection in the bring system because the specific fuel consumption for collection transports is lower than that for individual transports (Table 2). Only the kerbside collection of metal packaging results in fundamentally higher extra costs.

- With regard to acidification and net energy use, the recycling of metals plays an important role. Despite the small quantities collected, the recycling of metals has proven to lead to significant reductions in the environmental impact as compared to the other waste types (Table 8).

\footnotetext{
6 The far quicker production of carbon dioxide by burning versus the biological cycle of wood in the soil has not been taken into consideration.

7 Abfallwirtschaftsgesetz.
} 


\section{References}

Borken J, Patyk A, Reinhardt G. Basisdaten für ökologische Bilanzierungen. Wiesbaden (Germany): Vieweg; 1999.

Buwal, 1998. Bewertung von Oekobilanzen mit der Methode der oekologischen Knappheit—Oekofaktoren. Bern (Switzerland): Eigenverlag; 1997.

Coopers, Lybrand. Cost-benefit analysis of the different municipal solid waste management systems: objectives and instruments for the year 2000. Office for Official Publications of the European Communities, Final report. Luxembourg, Luxembourg; 1997.

Gallenkemper B, Brunnert M, Ölgemüller D. Behältersysteme und ihr Einfluss auf die Verwertung. Münster (Germany): Eigenverlag; 1992.

Hartard S. Entwicklung einer Indikatorenmethode zur Effizienzprüfung von Getrenntsammelsystmen in der Abfallwirtschaft. In: Bauhausuniversität Weimar [Hrsg.], Schriftenreihe des Lehrstuhls Abfallwirtschaft und des Lehrstuhl Siedlungswasserwirtschaft. Berlin (Germany): Rhombos Verlag; 2000.

Harvey LDD. Box models of the terrestrial biosphere. In Wigley, TML, Schimel, DS, editors. The carbon cycle. Cambridge (UK): Cambridge University Press; 2000.

ITU and Öko-Institut Darmstadt. Vergleichende Untersuchung zu den Umweltauswirkungen untrsschiedlicher Verfahren der Restabfallbehandlung. Darmstadt (Germany): Eigenverlag; 1994.

Klein Goldewijk K, Leemans R. Systems models of terrestrial carbon cycling. In Beran, MA, editors. Proceedings of the Conference on Prospects for Carbon Sequestration in the Biosphere on the Carbon Sequestration in the Biosphere, Processes and Prospects. July 1994, Heriot Watt University, Edinburgh, UK. Berlin, Germany: Springer; 1995.

Koller M, Soyez K. Ökologische Bilanzierung. In: Soyez K, editor. Mechanisch-biologische Abfallbehandlung: Technologien, Ablagerungsverhalten und Bewertung. Berlin (Germany): Erich Schmidt; 2001.

Schlesinger WH, Palmer Winkler J, Megonigal JP. Soils and the global carbon cycle. In Wigley, TML, Schimel, DS, editors. The Carbon Cycle. Cambridge, UK: Cambridge University Press; 2000.

Schwaiger, H-P. Güter- und Energieflüsse in der Abfallsammellogistik einer städtischen und ländlichen Region in der Steiermark. Diplomarbeit am Institut für Wassergüte und Abfallwirtschaft der TU Wien. Austria: Wien; 1996.

Seng, HJ. Umweltverträglichkeit bei Deponiestandorten. Dissertation. Stuttgart (Germany): Hochschulverlag; 1979.

Tiedemann A, Böttcher Tiedemann C, Buschardt A, Georgi B, Giersberg G, Goosmann G, ET AL. Ökobilanzen für graphische Papiere: Vergleich von Verwertungs- und Beseitigungsverfahren für graphische Altpapiere sowie Produktvergleiche für Zeitungsdruck-, Zeitschriften- und Kopierpapiere unter Umweltgesichtspunkten. Berlin (Germany): Umweltbundesamt; 2000.

White PR, Franke M, Hindle P. Integrated solid waste management-a lifecycle inventory. Gaithersburg (USA, MD): Aspen Publishers; 1999.

Wiemer K, Kern M. [Hrsg.]. Verfahrenstechnik der Bioabfallkompostierung. Reihe Abfallwirtschaft 10, Veröffentlichungen des Fachgebietes Abfallwirtschaft und Recycling in der Universität Kassel—Standort Witzenhausen. M.I.C. Baeza Verlag, Witzenhausen, Germany; 1992. 